\title{
Effects of chronic cortisol administration and daily acute stress on growth, physiological conditions, and stress responses in juvenile rainbow trout*
}

\author{
Bruce A. Barton**, Carl B. Schreck \& Lesley D. Barton** \\ Oregon Cooperative Fishery Research Unit $\cdots$, Oregon State University, Corvallis, Oregon 97331, USA
}

\begin{abstract}
Juvenile rainbow trout Salmo gairdneri were either fed cortisol or subjected to an acute stress daily for $10 \mathrm{wk}$ to determine the long-term effects of these factors on growth, physiological conditions, and stress responses. In fish fed cortisol, growth and condition factor, liver glycogen, and circulating lymphocytes were reduced and resting plasma glucose and hematocrit were increased. In fish stressed daily, all conditions were similar to those in controls except that lymphocyte numbers were lower. Continuous feeding of cortisol to fish for $10 \mathrm{wk}$ completely eliminated the plasma cortisol elevation after acute handling, but the magnitude of the stress-induced glucose increase was unchanged. In fish stressed daily for $10 \mathrm{wk}$, a reduction in post-stress levels of both plasma cortisol and glucose after handling demonstrated the effect of habituation on these stress responses. We concluded that continuously elevated plasma cortisol from exogenous feeding had a profound long-term effect on juvenile rainbow trout, but that daily stress-induced acute elevations of endogenous cortisol did not, except for a suppression of circulating lymphocytes. The occurrence of changes commonly observed in chronically stressed fish that are similar to those in the cortisol-fed trout in our experiment supports the view that long-term detrimental effects of stress in fish are largely mediated by cortisol. The results also indicated that continuous negative feedback of cortisol on the hypothalamic-pituitary axis may compromise the ability of fish to cope with additional stress factors by limiting their capacity to elicit an interrenal response to a stimulus.
\end{abstract}

\section{INTRODUCTION}

Biologists are familiar with the physiological responses of fish to stress (Pickering 1981), but mechanisms of action and the resultant consequences of stress on overall performance capacity are not yet well understood. Plasma corticosteroids, which affect both metabolic and immunologic pathways, rise dramatically in fish in response to stressful stimuli, particularly those that have a sensory component (reviewed by Donaldson 1981 and Schreck 1981). To attain our main

- Oregon State University, Agricultural Experiment Station Technical Paper No. 8060

- Present address: Utah Division of Wildlife Resources, Fisheries Experiment Station, 1465 West 200 North, Logan, Utah 84321, USA

-.. Cooperators are Oregon State University, U.S. Fish and Wildlife Service, and Oregon Department of Fish and Wildlife objective - determination of the consequences of continually elevated circulating cortisol in fish that would possibly result from long-term chronic stress - we examined the effects of chronic cortisol elevations in fish in the absence of other stressful stimuli. We fed cortisol to juvenile rainbow trout Salmo gairdneri and measured growth and condition, plasma cortisol and glucose, liver glycogen, hematocrit, and circulating leucocyte ratios. In addition, we determined the effect of continued cortisol treatment on the ability of the trout to elicit characteristic interrenal and glycemic responses to an acute stress. Our second objective - to assess the long-term effects on fish of being subjected to continual acute stresses, and the later effects of this treatment on characteristic stress responses - was approached by determining the effect of repeatedly elevating endogenous cortisol on these same physiological features by physically disturbing the fish daily. 


\section{MATERIALS AND METHODS}

Juvenile rainbow trout Salmo gairdneri (weight 4 to $5 \mathrm{~g}$ ) of the Willamette River stock were transferred from the Western Fish Toxicology Station, Corvallis, Oregon, USA, to the Oregon State University Smith Farm research facility $10 \mathrm{~d}$ before the study, for acclimation. Fish were held in circular tanks, $0.9 \mathrm{~m}$ in diameter, containing $327 \mathrm{l}$ of aerated flow-through well water and having an inflow rate of $2.81 \mathrm{~min}^{-1}$. Flows were directed into the tanks perpendicular to the surface of the water to reduce rotational current; all tanks were cleaned weekly but at least $5 \mathrm{~d}$ before any sampling. During acclimation, fish were fed at $2 \%$ of body weight per day with Oregon Moist Pellets. For the experiment, we fed duplicate tanks of 185 fish for each treatment once daily at $3 \%$ of body weight per day with either control or cortisol-treated Oregon Moist Pellets between 0900 and $1000 \mathrm{~h}$ for $10 \mathrm{wk}$. Extra care was taken to feed the fish slowly, to ensure that all feed pellets were consumed. The experimental diet was prepared by dissolving crystalline cortisol (Sigma Chemical Co., St. Louis, Missouri, USA) in 100\% ethanol and then spraying the resultant solution onto the surface of the pellets (Pickering 1984) to produce a concentration of $100 \mathrm{mg}$ cortisol $(\mathrm{kg} \text { feed })^{-1}$. The control diet was prepared by using an equivalent amount of ethanol only. Feed pellets were air-dried for $1 \mathrm{~h}$ with occasional stirring to evaporate the ethanol, and then refrozen. A third group of fish in duplicate tanks was fed the control diet, but was also subjected to an acute stress daily, 5 to $6 \mathrm{~h}$ after feeding, by one of the following 3 methods: (1) after capture, fish were held in the air for $30 \mathrm{~s}$ in a perforated bucket, (2) water was completely drained from the tanks and then allowed to fill at the normal inflow rate, or (3) fish were continually chased in the tanks with nets for $15 \mathrm{~min}$. The disturbance used was varied so that the fish would not become accustomed to a particular routine. During the $10 \mathrm{wk}$ experimental period (October to December 1984), fish were maintained under a natural photoperiod and at water temperatures ranging from a high of $13.0^{\circ} \mathrm{C}$ at the beginning of the study to a low of $11.5^{\circ} \mathrm{C}$ at the end.

At the beginning of the experiment and every $2 \mathrm{wk}$ thereafter, we removed 15 fish per tank to determine length, weight, and condition factor $\left(100 \times \mathrm{g} \mathrm{cm}^{-3}\right)$, and to sample blood, according to the following protocols: (1) from the control and cortisol-fed groups, 5 fish per tank were removed before feeding, and at 1 and $3 \mathrm{~h}$ after being fed; (2) from the stressed daily group, 5 fish per tank were removed before $6 \mathrm{~h}$ after feeding), and at 1 and $3 \mathrm{~h}$ after application of the stress. Feed rations were adjusted at each 2 wk interval in relation to the numbers and weights of fish remaining in the tanks, to keep the relative ration constant.

Blood samples from the beginning of the study ( 0 wk), and at 4 and 8 wk were obtained for cortisol and glucose analyses. Cortisol was determined by radioimmunoassay (Foster \& Dunn 1974), as modified by Redding et al. (1984b) for use with salmonid plasma and verified for Salmo gairdneri by Barton \& Schreck (in press a). We measured glucose by the orthotoluidine method (Wedemeyer \& Yasutake 1977), using premixed reagent (Sigma Chemical Co.). Blood samples taken 2 wk after the onset of treatment were used for determinations of hematocrit and leucocyte number. Hematocrit, also measured after $6 \mathrm{wk}$, was determined as percent packed cell volume after centrifugation. We determined leucocyte ratios from Giesma-stained blood smears by counting erythrocytes (average 1386 per slide, range 738 to 2024) and lymphocytes and other leucocytes in 15 random fields per slide (i.e. per fish), using Yasutake \& Wales (1983) as a reference. Liver samples for determinations of hepatosomatic index $(100 \times$ liver wet weight/body wet weight) and glycogen, and stomach tissues for histological examination, were obtained after $10 \mathrm{wk}$. Whole livers were immediately placed in preweighed vials containing chilled $30 \% \mathrm{KOH}$, and hepatic glycogen was later analyzed by the method of Montgomery (1957). Cardiac portions of stomachs from control and cortisol-fed fish were preserved in buffered $10 \%$ formalin. After histological preparation, we qualitatively evaluated slide-mounted sections, $6 \mu \mathrm{m}$ thick and stained with hematoxylin and eosin, for evidence of tissue degradation or other abnormalities.

At Week 10, the fish in control and cortisol-fed groups were each separated into 2 subgroups, one of which remained in the 'home' tank. The fish remaining in all 'home' tanks were then subjected to a handling stress (held in the air in a perforated bucket for $30 \mathrm{~s}$, as described earlier). Blood samples for cortisol and glucose analyses were taken before any disturbance (initial) and at 1, 3, 6, 12 and $24 \mathrm{~h}$ after handling.

The second subgroups of fish from the control and cortisol-fed groups were placed in $100 \mathrm{l}$ tanks and feeding was continued with their respective diets. After $2 \mathrm{~d}$, both groups were fed with a single meal of cortisoltreated feed at $3 \%$ of body weight, to characterize the profile of cortisol in the blood over $24 \mathrm{~h}$ post-feeding and the resultant effect on plasma glucose. Blood samples were obtained just before the fish were fed and at $1,3,6,12$ and $24 \mathrm{~h}$ after feeding.

Cumulative percent increases in mean weight of fish were compared by linear regression of $2 \mathrm{wk}$ growth increments in each tank; slope of regression represents the percent change in body weight per day for the growth period. Differences from controls were assessed 
by comparing variances of slopes using Student's ttests $(\mathrm{p}<0.05$ and $<0.01$ ). Specific (instantaneous) growth rates were calculated as:

$$
\left(\left[\ln \text { weight }_{2}-\ln \text { weight }_{1}\right] / \text { days fed }\right) \times 100
$$

(Ricker 1979). Multiple-point comparisons were made by using 1-way analyses of variance followed by Duncan's new multiple-range tests at the $5 \%$ level (Steel \& Torrie 1980); 2-point comparisons were made with Student's t-tests $(p<0.05)$. Because of variance heterogeneity (Bartlett's test: Snedecor \& Cochran 1967), data for cortisol and glucose were transformed to logarithmic values for analysis.

\section{RESULTS AND DISCUSSION}

\section{Growth and resting physiological conditions}

Relative growth in the cortisol-fed trout was reduced, but growth in the fish stressed daily was not different from that in controls (Fig. 1). Specific growth rate for the 10 wk period was lowest in the fish fed cortisol (Table 1). All 3 groups showed initial reductions in specific growth rates, followed by increases mid-way through the growth period (Table 1). This change may reflect a normal cyclical variation in growth rates in rainbow trout of this size (Wagner \& McKeown 1985). Davis et al. (1985), using the same experimental protocol that we used, observed a reduction in absolute growth and condition factor in cortisol-fed channel catfish Ictalurus punctatus. Although they attributed the reduced growth to the presence of cortisol in the diet, they were unable to demonstrate a concomitant increase in blood corticosteroids after cortisol had been fed. However, Davis et al. (1985) did find an increase in activity of hepatic tyrosine aminotransferase in cortisolfed fish and concluded that increased corticosteroidinduced gluconeogenesis resulted in decreased growth. In contrast to our finding for fish stressed daily, Peters \& Schwarzer (1985) reported significantly reduced growth of juvenile rainbow trout subjected to a daily, brief handling stress over $4 \mathrm{wk}$, but did not indicate whether they considered this to be a cortisolmediated phenomenon.

The continual application of dietary cortisol to the juvenile rainbow trout also reduced the condition factor over the 10 wk period (Table 2). Robertson et al. (1963) found that pharmacological doses of cortisol produced a rapid weight loss in juvenile rainbow trout, and Pickering \& Duston (1983) observed that both orally administered and implanted cortisol at physiological levels significantly reduced the condition factor of brown trout Salmo trutta.

As Davis et al. (1985) pointed out, continuous stress may result in reduced growth by chronically elevating plasma cortisol and thereby shifting metabolism toward protein catabolism. Pickering \& Stewart (1984)

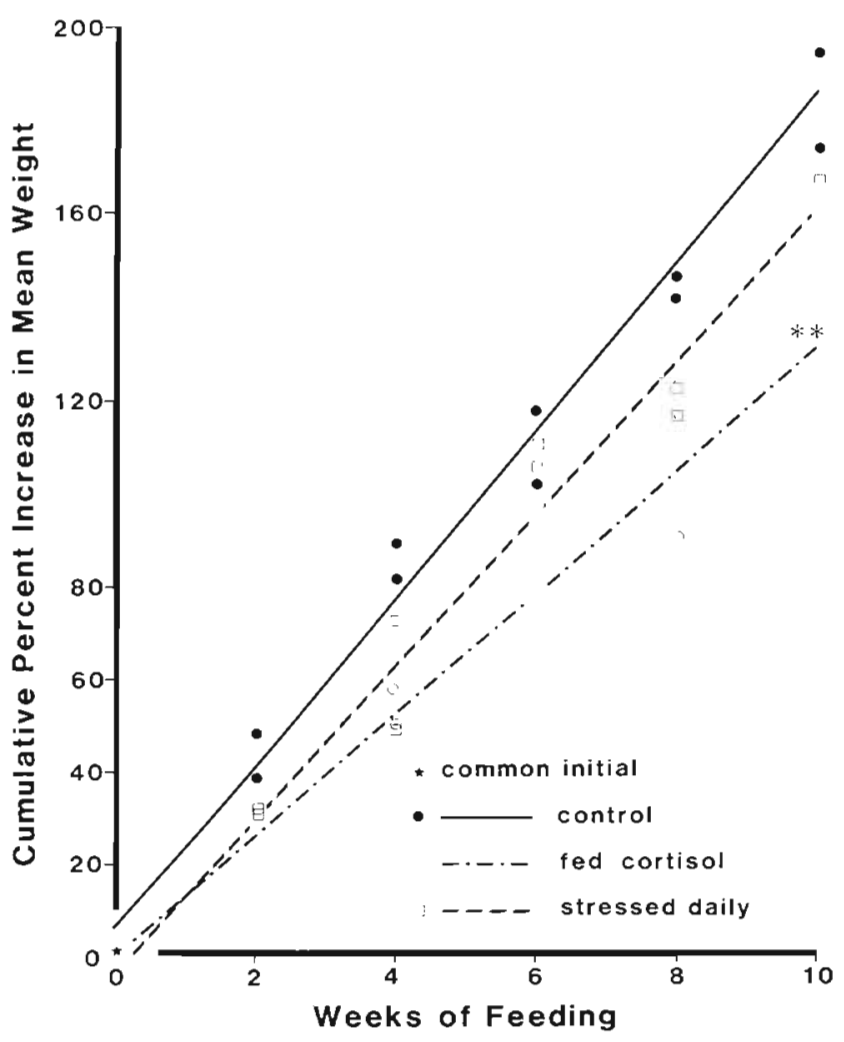

Fig. 1. Salmo gairdneri. Cumulative percent increase in mean weight ( $\mathrm{n}=15$ per replicate, 2 replicates per sample week) of juvenile rainbow trout fed either cortisol-treated or control feed, or fed control feed and subjected to an acute stress daily, for $10 \mathrm{wk}$. Relative growth as $\%$ increase $\mathrm{d}^{-1}$ for each treatment is represented by the slope of the line. ** Significant difference $(p<0.01)$ in slope from control

Table 1. Salmo gairdneri. Specific growth rates at $2 \mathrm{wk}$ intervals and mean initial and final weights $(\mathrm{g} \pm \mathrm{SE}, \mathrm{n}=30)$ of juvenile rainbow trout fed either cortisol-treated or control feed, or fed control feed and subjected to an acute stress daily, for $10 \mathrm{wk}$. Data represent pooled values from duplicate tanks for each treatment

\begin{tabular}{|lccc|}
\hline $\begin{array}{c}\text { Growth charac- } \\
\text { teristic and week }\end{array}$ & Control & $\begin{array}{c}\text { Treatment } \\
\text { Fed cortisol }\end{array}$ & Stressed daily \\
\hline Specific growth rate & & & \\
Week 2 & 2.52 & 1.36 & 1.59 \\
Week 4 & 2.59 & 2.02 & 2.32 \\
Week 6 & 1.59 & 1.98 & 2.63 \\
Week 8 & 2.20 & 0.49 & 0.89 \\
Week 10 & 2.40 & 2.31 & 2.60 \\
Mean, 10wk & 2.26 & 1.65 & 2.02 \\
Weight (g) & & & \\
Week 0 & $4.5 \pm 0.2$ & $4.3 \pm 0.2$ & $5.2 \pm 0.2$ \\
Week 10 & $21.4 \pm 0.7$ & $13.4 \pm 0.5$ & $21.0 \pm 1.0$ \\
& & & \\
\end{tabular}


Table 2. Salmo gairdneri. Mean liver. glycogen ( $\mathrm{mg} \mathrm{g}^{-1} \pm \mathrm{SE}, \mathrm{n}=9$ to 12 ), hepatosomatic index $( \pm \mathrm{SE}, \mathrm{n}=12$ ) and condition factor ( $\pm \mathrm{SE}, \mathrm{n}=12$ ) in juvenile rainbow trout fed either cortisol-treated or control feed, or fed control feed and subjected to an acute stress daily, after $10 \mathrm{wk}$ of treatment. Values represent pooled data from duplicate tanks for each treatment

\begin{tabular}{|c|c|c|c|}
\hline Treatment & Liver glycogen & Hepatosomatic index & Condition factor \\
\hline Control & $35 \pm 2.6$ & $1.38 \pm 0.07$ & $1.29 \pm 0.02$ \\
\hline Fed cortisol & $11 \pm 1.6^{\circ}$ & $0.88 \pm 0.04^{\circ}$ & $1.11 \pm 0.01^{\circ}$ \\
\hline Stressed daily & $31 \pm 2.8$ & $1.19 \pm 0.05^{\circ}$ & $1.26 \pm 0.02$ \\
\hline
\end{tabular}

found that chronically crowded brown trout grew less than uncrowded controls fed the same ration; however, plasma cortisol initially rose but had returned to the level of the control group by $39 \mathrm{~d}$. They concluded that long-term growth suppression was not mediated by corticosteroids, but may have been caused by reduced grew less.
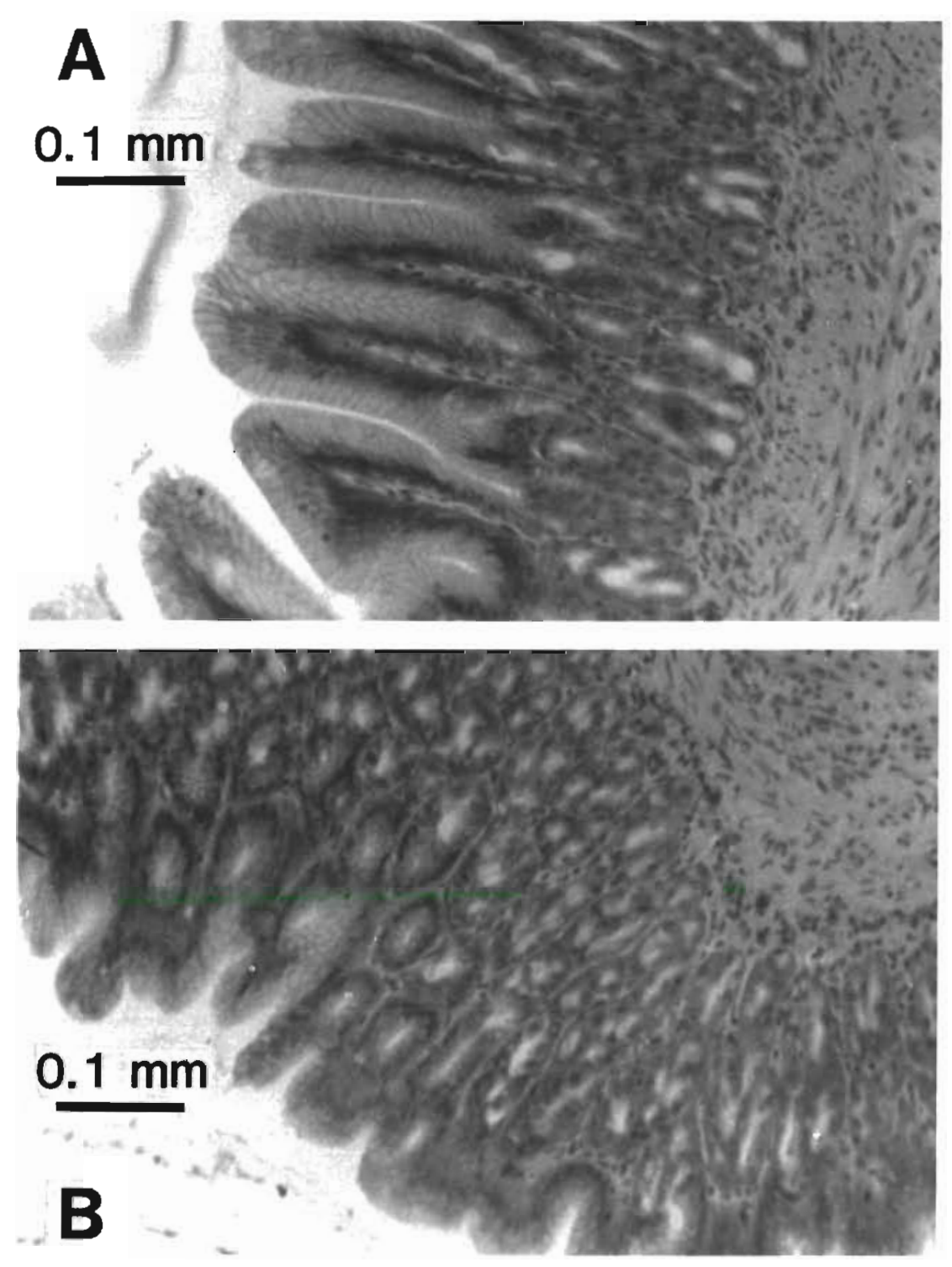

food intake or decreased efficiency in food utilization relating to social interactions from crowding. For example, Strange et al. (1978) noted that juvenile chinook salmon Oncorhynchus tshawytscha stressed by high density confinement refused food, and subsequently

Fig. 2. Salmo gairdneri. Cardiac stomach tissue of similar-sized (A) control and (B) cortisol-fed juvenile rainbow trout after 10 wk of treatment, showing apparent reduction of mucosal folds and increases in gastric gland cell numbers and vacuolar spaces. Scale bar $=0.1 \mathrm{~mm}$ 
As an alternative explanation for the reduced growth in our experimental fish, chronic cortisol administration possibly affected digestion efficiency at the gut wall. We observed a loss of both appetite and aggressive feeding behavior in fish fed cortisol, even though all feed pellets presented to the fish were eaten. There was a noticeably higher accumulation of fecal matter at the bottom of the tanks of the cortisol-fed fish than in those of control fish, suggesting poorer absorption of the food material in the gut. We also noticed qualitative differences in the cardiac stomach tissue of control and cortisol-fed fish (Fig. 2), characterized in the fish fed cortisol by apparent increases in gastric gland cell numbers and vacuolar spaces and reductions in the height of mucosal folds. However, the small size of our sample precluded a conclusion that these changes were representative of the treated population, and we were unable to resolve differences at the cellular level. Our observations of morphological alterations to cardiac stomach tissues in cortisol-fed trout are consistent with those of other investigators in fish with chronically elevated cortisol. In rainbow trout implanted with cortisol pellets, Robertson et al. (1963) reported necrosis of gastric glands and submucosa as well as a reduction in the number and height of mucosal folds. McBride \& van Overbeeke (1971) also noticed atrophy of the mucosa and a reduction in epithelial cell height in stomachs of sockeye salmon Oncorhynchus nerka injected repeatedly with cortisol for 4 wk. Similar cellular and tissue degeneration was found by Peters (1982) and Willemse et al. (1984) in stomachs of European eels Anguilla anguilla under conditions of chronic stress. Peters (1982) further speculated that the resultant alterations in enzyme and acid secretion in the mucosa could interfere with normal protein digestion, and thus lead to reduced growth.

There was a noticeable increase in the post-feeding elevation of plasma cortisol in fish fed with cortisol for 4 and $8 \mathrm{wk}$, as compared to fish from Week 0 (Fig. 3). Fish stressed daily had lower $1 \mathrm{~h}$ post-stress plasma cortisol levels after 4 and $8 \mathrm{wk}$ of treatment than at $0 \mathrm{wk}$, whereas plasma cortisol in control fish remained relatively unchanged after $1 \mathrm{~h}$ as a result of feeding (Fig. 3). However, our sampling regime may have missed a transitory post-feeding increase in plasma cortisol within the first hour such as that demonstrated by Pickering \& Pottinger (1983) in brown trout. The trend to higher cortisol concentrations at 1 and $3 \mathrm{~h}$ after feeding in cortisol-treated fish was also evident at Week 10 when compared to corresponding plasma levels in fish that had not been previously fed cortisol (Fig. 4). We speculate that chronic cortisol treatment resulted in an increased rate of absorption after feeding by altering physical absorption characteristics across the gut wall, perhaps through a pharmacological action

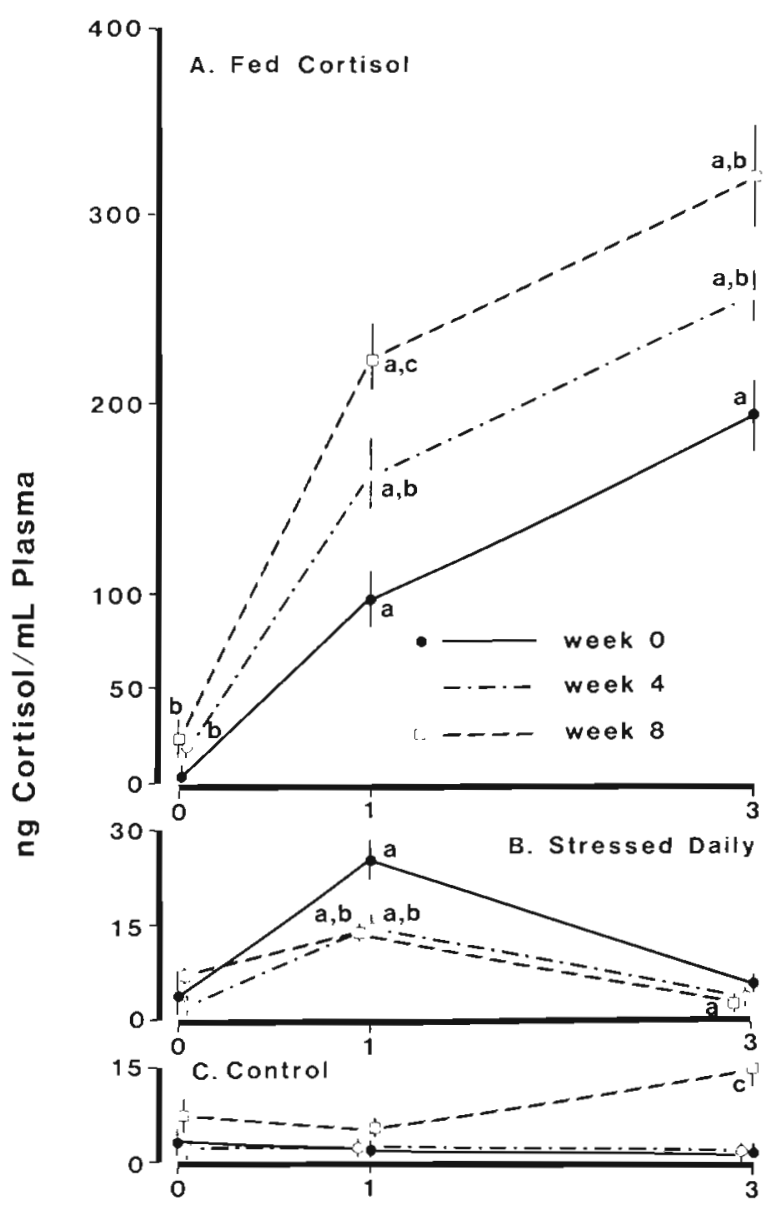

Hours after Feeding (A \& C) or Stress (B)

Fig. 3. Salmo gairdneri. Mean plasma cortisol levels (ng $\mathrm{ml}^{-1}$ $\pm \mathrm{SE}, \mathrm{n}=10$ ) in juvenile rainbow trout at 0,4 and $8 \mathrm{wk}$ of treatment. (A) Trout given cortisol-treated feed; levels before $(0 \mathrm{~h})$ and 1 and $3 \mathrm{~h}$ after being fed. (B) Trout given control (untreated) feed and stressed daily; levels before and after a $30 \mathrm{~s}$ handling stress. (C) Trout given control feed; levels before $(0 \mathrm{~h})$ and 1 and $3 \mathrm{~h}$ after being fed. Values represent pooled data from duplicate tanks for each treatment. Superscripts indicate significant differences $(p<0.05)$ as follows: adifferent from $0 \mathrm{~h}$ (initial) after treatment for that week;

${ }^{\mathrm{b}}$ different from Week 0 for that hour; ${ }^{\mathrm{c}}$ different from Weeks 0 and 4 for that hour

such as cellular degradation. Cortisol levels were the same, however, at 6 and $12 \mathrm{~h}$ after feeding and were lower in the fish fed cortisol for $10 \mathrm{wk}$ than in the control group after $24 \mathrm{~h}$ (Fig. 4), suggesting more rapid clearance in the treated fish. Chronically elevated plasma cortisol, resulting from cortisol administered in implanted capsules, has been shown previously to increase clearance rate of corticosteroids in coho salmon Oncorhynchus kisutch (Redding et al. 1984a). Of interest was the straight line formed by declining postfeeding cortisol concentrations in the fish that were fed cortisol for $10 \mathrm{wk}$ (Fig. 4) since clearance rate is non- 


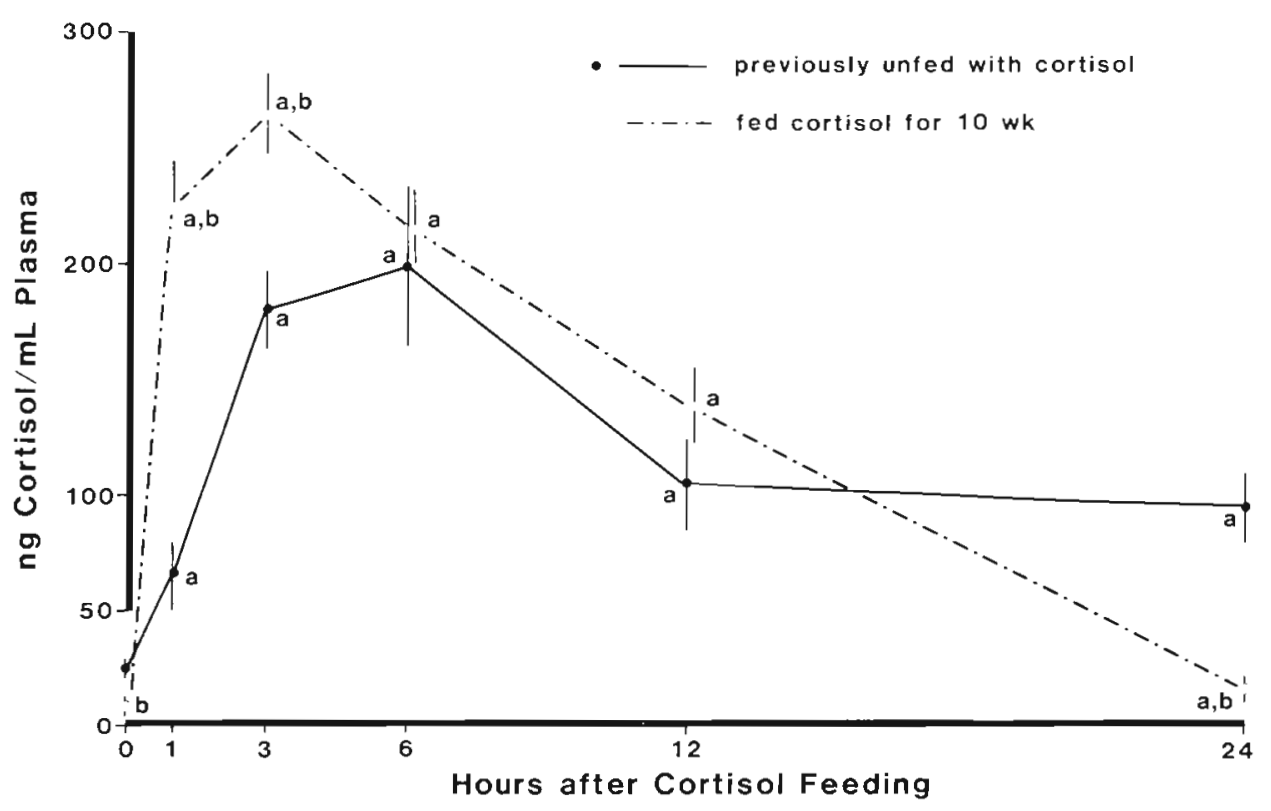

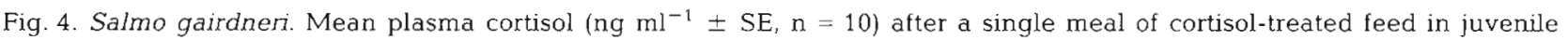
rainbow trout, previously fed either cortisol-treated or control feed for $10 \mathrm{wk}$. Values represent pooled data from duplicate tanks for each treatment. Superscripts indicate significant differences $(\mathrm{p}<0.05)$ as follows: different from $0 \mathrm{~h}$ (initial) within that treatment ${ }^{b}$ different from value for fish previously untreated with cortisol for that hour

linear under normal conditions (e.g. Nichols \& Weisbart 1985, Nichols et al. 1985) and decreases with concentration.

Plasma glucose was elevated in fish after 4 and 8 wk of cortisol treatment both before (i.e. $24 \mathrm{~h}$ after last feeding) and after feeding (Fig. 5). In the fish stressed daily, glucose levels at Weeks 0,4 , and 8 were similar to each other and showed the same post-stress increase after $1 \mathrm{~h}$ (Fig. 5). Post-feeding plasma glucose in control fish remained relatively stable at 4 and $8 \mathrm{wk}$, but showed an increase in the Week 0 group (Fig. 5). Plasma glucose in fish fed cortisol for $10 \mathrm{wk}$ was characterized by a more rapid increase, followed by a more rapid decline in concentration after a cortisoltreated ration than that found in control fish given the same treatment (Fig. 6). Judging from post-feeding levels at 1 and $3 \mathrm{~h}$ (Fig. 5C) and at $6 \mathrm{~h}$ (prestress values in Fig. 5B), feeding alone did not appear to alter plasma glucose appreciably.

Increased plasma glucose in fish after 2 wh of feeding with cortisol is consistent with findings in previous investigations (Butler 1968, Patent 1970, Inui \& Yokote 1975, Lidman et al. 1979, Leach \& Taylor 1982). In many of these studies, high doses of cortisol were applied by injection, thereby introducing the possibility that hepatic glycogenolysis, stimulated by stressinduced catecholamine secretion (Nakano \& Tomlinson 1967. Mazeaud et al. 1977), also modified plasma glucose. Davis et al. (1985) observed no increase in plasma glucose after they fed exogenous cortisol to fish. Our findings of higher resting plasma glucose with chronic cortisol feeding and the apparently cortisol-related transient change in glucose after a single cortisol meal both support the glucocorticoid role of cortisol in teleosts and corroborate the earlier conclusion by Davis et al. (1985) that increased gluconeogenesis resulted in reduced growth. Moreover, our results clearly showed that dietary cortisol appeared in circulation at physiological levels soon after feeding. The concentrations of plasma cortisol we observed at 1 to $6 \mathrm{~h}$ after feeding were similar to those found in juvenile salmonids after either a severe acute stress such as handling or chronic stress from confinement (Strange et al. 1977. 1978, Barton et al. 1980, 1985b, 1986, Strange \& Schreck 1980, Pickering et al. 1982, 1986, Redding \& Schreck 1983).

After $10 \mathrm{wk}$, liver glycogen and hepatosomatic index were reduced in the fish fed cortisol (Table 2); the hepatosomatic index was also lower in fish stressed daily than in control fish. The large reduction in liver glycogen resulting from the feeding of cortisol is unusual in light of earlier investigations that showed increases in liver glycogen in fish after cortisol treatment (Butler 1968, Hill \& Fromm 1968, Swallow \& Fleming 1970, Inui \& Yokote 1975, Lidman et al. 1979) or in fish with elevated endogenous plasma cortisol (Schmidt \& Idler 1962). Other studies have indicated, however, that cortisol treatment can reduce liver glycogen in fish (Storer 1967, Ball \& Hawkins 1976), or that endogenous plasma cortisol and liver glycogen are 
inversely related (Peters et al. 1980, Paxton et al. 1984). These conflicting reports suggest that there are differences in cortisol-treatment effects on carbohydrate metabolism that are due to the physiological status of the fish, dosages of cortisol used, or interactions of cortisol with other glucoregulatory hormones. The low liver glycogen observed in the fish fed cortisol may also have resulted from a chronically increased metabolic rate. Cortisol injections have been found to increase metabolic rate in fish (Chan \& Woo 1978) and there is a significant correlation between standard metabolic rate and blood sugar levels in vertebrates generally (Umminger 1977). An increased metabolic rate could also have contributed to the reduced growth in our cortisol-fed fish by shifting energy away from growth pathways (Brett \& Groves 1979).

\section{Hematological characteristics}

After 2 and $6 \mathrm{wk}$, hematocrit was higher in fish fed with cortisol but was not appreciably altered in the fish stressed daily, compared with that in the respective controls (Table 3). After 2 wk, lymphocyte ratios were $84 \%$ lower than control values in cortisol-fed fish and $31 \%$ lower in fish stressed daily (Table 3). Combined neutrophil and thrombocyte ratios were not different among treatments (Table 3 ).

The higher hematocrit in the fish fed cortisol than in untreated fish after $2 \mathrm{wk}$ is interesting in that this phenomenon has not been observed in fish in which plasma cortisol was chronically elevated by using implants (J. M. Redding \& C. B. Schreck unpubl.) or that were treated with single or multiple cortisol injections (Johansson-Sjobeck et al. 1978, Leatherland 1985). An increase in hematocrit may be caused by an alteration in intracellular or extracellular fluid or by proliferation in erythrocytes. Pickford et al. (1970) found that repeated injections of cortisol significantly increased the erythrocyte count in the mummichog Fundulus heteroclitus, although reasons were not given. We observed no evidence of increased hemopoietic activity in blood smears from cortisol-treated fish, which would be apparent as increased numbers of immature erythrocyte stages. This lack of increase suggests that the increased hematocrit we observed possibly resulted from a cortisol-mediated decrease in extracellular fluid relative to blood cell volume. In adrenalectomized European eels, Chan et al. (1969) found that cortisol treatment increased the glomular filtration rate and urine production. Such a response from cortisol feeding could account for a reduced blood fluid volume and a resultant higher hematocrit.

A number of authors have also found that physical stress increases hematocrit in fish (Soivio \& Oikari

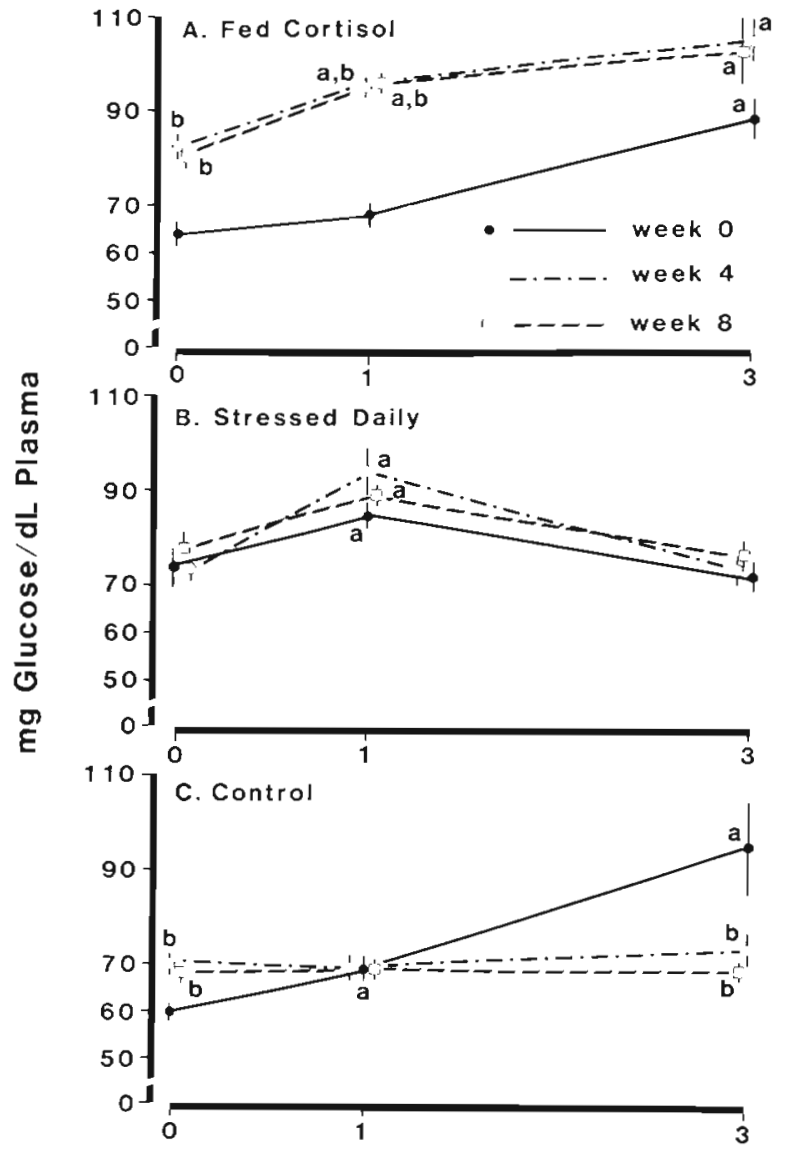

Hours after Feeding (A \& C) or Stress (B)

Fig. 5. Salmo gairdneri. Mean plasma glucose levels (mg $\mathrm{dl}^{-1}$ $\pm \mathrm{SE}, \mathrm{n}=8$ to 10 ) in juvenile rainbow trout at 0,4 and $8 \mathrm{wk}$ of treatment. (A) Trout given cortisol-treated feed; levels before $(\mathrm{O})$ and 1 and $3 \mathrm{~h}$ after being fed. (B) Trout given control (untreated) feed and stressed daily; levels before and after a $30 \mathrm{~s}$ handling stress. (C) Trout given control feed; levels before $(0 \mathrm{~h})$ and 1 and $3 \mathrm{~h}$ after being fed. Values represent pooled data from duplicate tanks for each treatment. (See

Fig. 3 for explanation of significance)

1976, Wells et al. 1984, Barton et al. 1985b), and that this increase may be due to swelling of the erythrocytes, accompanied by a redistribution of body fluids (Milligan \& Wood 1982). However, there is no evidence to indicate that this effect is mediated by cortisol. Moreover, this phenomenon appears to be a transient response to acute disturbances, since we saw no difference in hematocrit between the controls and the fish stressed daily. Similarly, Pickering \& Pottinger (1985) found that a daily acute stress of exposure to malachite green had no long-term effect on hematocrit in brown trout.

The depression in numbers of circulating lymphocytes (but no change in neutrophils or thrombocytes) was caused by the dietary cortisol, and confirms a 


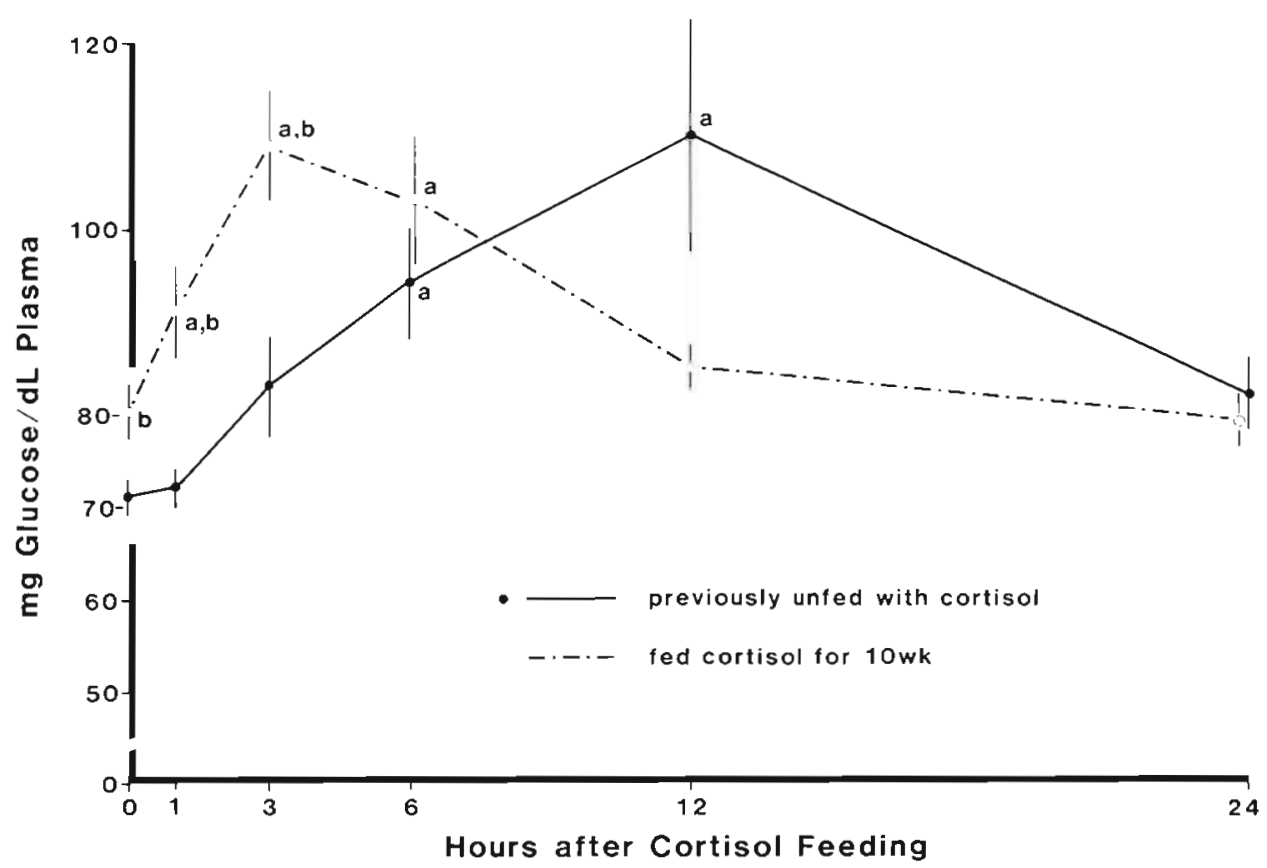

Fig. 6. Salmo gairdneri. Mean plasma glucose $\left(\mathrm{mg} \mathrm{dl^{-1 }} \pm \mathrm{SE}, \mathrm{n}=10\right)$ after a single meal of cortisol-treated feed in juvenile rainbow trout, previously fed either cortisol-treated or control feed for 10 wk. Values represent pooled data from duplicate tanks for each treatment. (See Fig. 4 for explanation of significance)

Table 3. Salmo gairdneri. Mean hematocrit (\% packed cell volume $\pm \mathrm{SE}, \mathrm{n}=18$ to 20) after 2 and 6 wk of treatment, and mean lymphocyte ratio and combined neutrophil and thrombocyte ratio (no. cells per $10^{3}$ red blood cells $\pm S E, n=12$ ) after 2 wk of treatment, in juvenile rainbow trout fed either cortisol-treated or control feed, or fed control feed and subjected to an acute stress daily. Values represent pooled data from duplicate tanks for each treatment

\begin{tabular}{|c|c|c|c|}
\hline Blood characteristic & Contro] & $\begin{array}{l}\text { Treatment } \\
\text { Fed cortisol }\end{array}$ & Stressed daily \\
\hline \multicolumn{4}{|l|}{ After $2 \mathrm{wk}$ of treatment } \\
\hline Hematocrit & $45 \pm 0.9$ & $53 \pm 0.8^{\circ}$ & $45 \pm 0.7$ \\
\hline Lymphocyte ratio & $25 \pm 3.4$ & $4.1 \pm 1.1^{\circ}$ & $18 \pm 1.5^{\circ}$ \\
\hline Neutrophil and thrombocyte ratio & $1.0 \pm 0.3$ & $1.1 \pm 0.2$ & $1.1 \pm 0.3$ \\
\hline \multicolumn{4}{|l|}{ After 6 wk of treatment } \\
\hline Hematocrit & $43 \pm 0.7$ & $54 \pm 0.8^{\circ}$ & $42 \pm 1.0$ \\
\hline
\end{tabular}

similar observation by Pickering (1984). Although there was a $22 \%$ increase in hematocrit, this increase alone (if due to hemopoiesis) cannot account for the reduction in lymphocyte number to one-fifth of that in control fish. Pickering (1984) found that when brown trout were fed a single meal containing an amount of cortisol equivalent to that we used, lymphocyte numbers were reduced by about $65 \%$ but returned to normal in $72 \mathrm{~h}$. Our results suggested that lymphocyte numbers do not compensate, but will probably remain low as long as the cortisol concentration is continually elevated. This observation contradicts that of Pickford et al. (1970) who, after finding an increased white blood cell count in mummichog, concluded that the fish showed an adap- tive response to chronic cortisol treatment. It has been previously shown that an injection of cortisol into fish also reduces circulating lymphocyte numbers (McLeay 1973, Ball \& Hawkins 1976) and that exogenous cortisol treatment increases the susceptibility of fish to various diseases (Robertson et al. 1963, Roth 1972, Pickering \& Duston 1983). Grimm (1985) recently found that physiological levels of cortisol suppressed the mitogeninduced proliferation of leucocytes from plaice Pleuronectes platessa cultured in vitro, suggesting that this may be an important part of the mechanism by which stress reduces disease resistance. Moreover, Maule et al. (1987) found that as coho salmon underwent smoltification, their ability to generate in vivo antibody- 


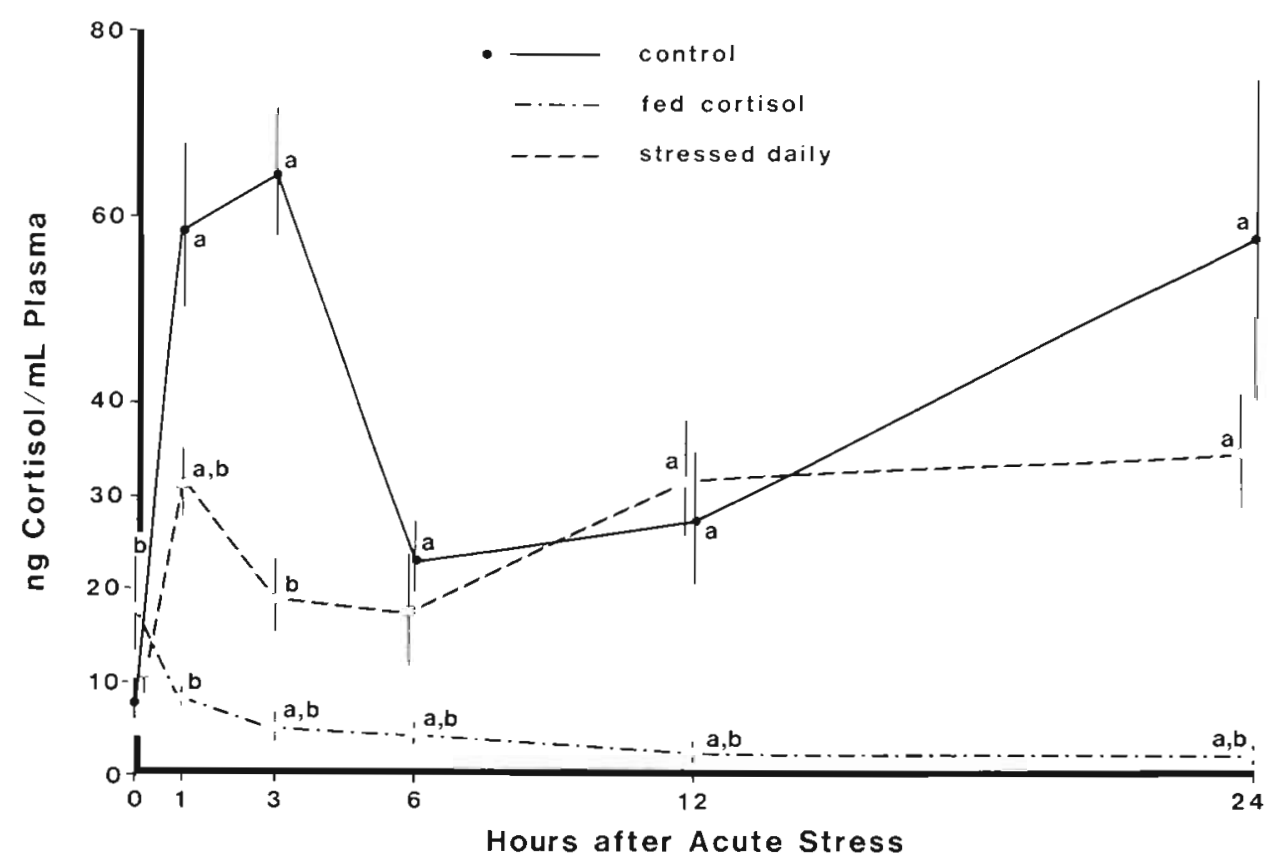

Fig. 7. Salmo gairdneri. Mean plasma cortisol ( $\mathrm{ng} \mathrm{m} \mathrm{m}^{-1} \pm \mathrm{SE}, \mathrm{n}=12$ ) after a $30 \mathrm{~s}$ handling stress in juvenile rainbow trout previously fed either cortisol-treated or control feed, or fed control feed and subjected to an acute stress daily, for 10 wk. Values represent pooled data from duplicate tanks for each treatment. Superscripts indicate significant differences $(p<0.05)$ as follows:

adifferent from $0 \mathrm{~h}$ (initial) within that treatment; ${ }^{b}$ different from control treatment for that hour

producing cells in the spleen declined and the relative numbers of spleen cells decreased. These changes noted by Maule et al. (1987) were accompanied by increased cortisol concentrations in the fish.

The reduced number of blood lymphocytes in the fish stressed daily after $2 \mathrm{wk}$ of treatment was of particular interest. Various forms of stress have been shown to reduce circulating lymphocyte or leucocyte numbers (Esch \& Hazen 1980, Hlavek \& Bulkley 1980, Peters et al. 1980, Pickering et al. 1982, Klinger et al. 1983), leucocrit (McLeay \& Gordon 1977, Tomasso et al. 1983, Wedemeyer et al. 1983) and possibly lymphocyte function (Ellsaesser \& Clem 1986); see review by Fries (1986). Pickering (1984) concluded that this stressinduced response is mediated by cortisol. A positive association between environmental stress and the outbreak of disease in fish is also well established (Wedemeyer 1970, Snieszko 1974, Walters \& Plumb 1980, Wedemeyer \& Goodyear 1984). Our finding implies that the routinely handled fish may still have been less resistant to disease, even though their growth and other physiological conditions appeared normal.

\section{Stress responses}

When fish fed cortisol for $10 \mathrm{wk}$ were subjected to a 30 s handling stress, plasma cortisol did not increase, as it did in the control group. From 3 h onward, post-stress cortisol levels were lower than the initial prestress level (Fig. 7) in the cortisol-treated fish. Plasma cortisol 1 and $3 \mathrm{~h}$ after handling was noticeably lower in the fish stressed daily than in controls (Fig. 7). Although both control fish and those stressed daily evoked a stress response characterized by a rapid rise in plasma cortisol followed by a decline, concentrations in both groups rose again at $12 \mathrm{~h}$ and were still elevated after $24 \mathrm{~h}$ (Fig. 7).

The chronic treatment with cortisol eliminated the ability of the fish to elicit an elevation in cortisol after handling. In fact, plasma cortisol declined after handling, suggesting that residual cortisol in circulation was rapidly used peripherally or cleared as a result of the stress. Cortisol secretion from interrenal tissue in fish is regulated by negative feedback on the hypothalamus to inhibit synthesis or release of corticotropin-releasing factor (CRF) that, in turn, suppresses adrenocorticotropic hormone (ACTH) secretion from the pituitary (Fryer \& Peter 1977). Although interrenal cells were not measured, continual negative feedback in the fish treated with cortisol may have caused an atrophy of these steroidogenic cells as a result of the continued absence of stimulation by ACTH. Basu et al. (1965), who found that a dose- and time-dependent atrophy of interrenal tissue was induced by cortisol injections in the cichlid Tilapia mossambica, concluded that continued presence of the cortisol probably inhibited ACTH secretion. 


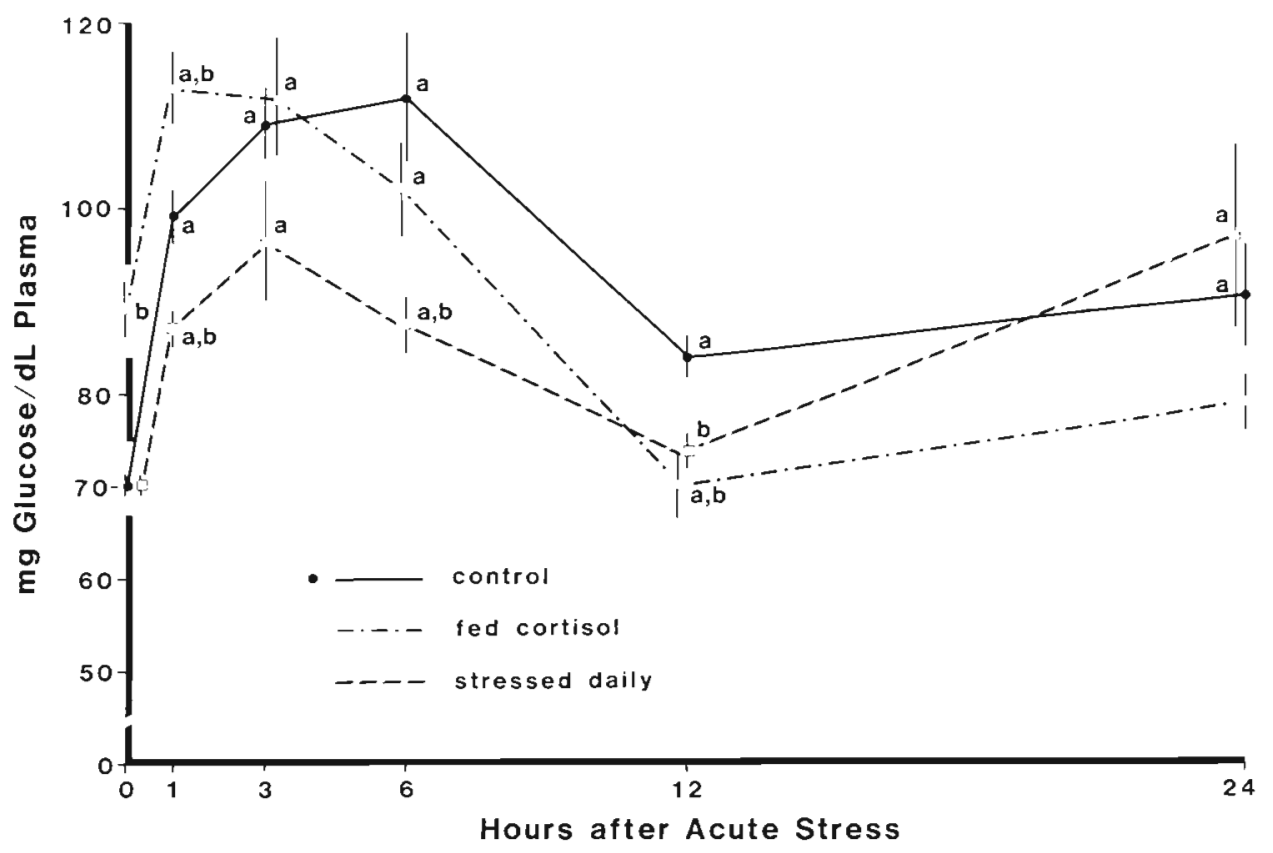

Fig. 8. Salmo gairdneri. Mean plasma glucose $\left(\mathrm{mg} \mathrm{dl}^{-1} \pm \mathrm{SE}_{\mathrm{a}} \mathrm{n}=11\right.$ or 12$)$ after a $30 \mathrm{~s}$ handling stress in juvenile rainbow trout previously fed either-cortisol-treated or control feed, or fed control feed and subjected to an acute stress daily, for 10 wk. Values represent pooled data from duplicate tanks for each treatment. (See Fig. 7 for explanation of significance)

Plasma glucose was elevated in response to handling in all 3 treatment groups (Fig. 8) but reached peak levels sooner in the fish fed cortisol. However, since initial plasma glucose was highest in the cortisol-fed fish, the relative increases in glucose were similar in both the cortisol-fed and control groups (Fig. 8). Plasma glucose $12 \mathrm{~h}$ after handling in the group fed cortisol was lower than the initial level and lower than in control fish at that time (Fig. 8). The response patterns of plasma glucose to handling were similar in control fish and those stressed daily, though the magnitude of the elevation was less in the stressed fish (Fig. 8).

Although resting plasma glucose was elevated, cortisol treatment did not appear to affect the hyperglycemic response to handling. Acute stress-induced plasma glucose elevations are mediated by catecholamines (Mazeaud et al. 1977. Mazeaud \& Mazeaud 1981) and our finding supports the view that corticosteroids are probably not involved directly in this initial response (Leach \& Taylor 1980, Carmichael et al. 1984, Barton et al. 1986).

Except for the secondary increases at $24 \mathrm{~h}$, the responses of cortisol and glucose to short-term handling in control fish were typical of those seen in juvenile salmonids (Strange et al. 1977, Barton et al. 1980, 1985b, 1986, Pickering et al. 1982, Barton \& Schreck in press b). However, the reduced plasma cortisol and glucose responses observed in the fish stressed daily clearly indicated the effect of preconditioning. A significant proportion of the normal stress response is believed to be due to the novelty of the stimulus (Levine 1985). We are unaware of other investigations on the effect of habituation on acute responses of cortisol to handling in fish, but Pickering \& Pottinger (1985) showed that daily exposure to malachite green eliminated the cortisol stress response in brown trout after $4 \mathrm{wk}$. Studies with rats conditioned to exercise indicated that the reduced corticosteroid response in conditioned specimens was not due to adrenal exhaustion, but rather to adaptation of both the hypothalamicpituitary axis (Frenkl et al. 1968) and the adrenal gland (Tharp \& Buuck 1974). Similarly, Rees et al. (1983. 1985 found that the corticosterone response was reduced in ducks after they were habituated to daily exercise stress and exercise plus handling. The investigators concluded that this reduction was caused by reduced endogenous $\mathrm{ACTH}$ secretion in response to the stimulus, since the cortisol response to exogenous ACTH was unchanged (Rees et al. 1985).

Using a daily habituation protocol similar to ours, Rush \& Umminger (1978) abolished the stress-induced hyperglycemic response in goldfish Carassius auratus in 3 wk. Woodward \& Smith (1985) found that trained rainbow trout elicited significant hyperglycemia to a disturbance, whereas untrained fish did not; they attributed this difference to a post-stress increase in epinephrine in the trained fish that was not apparent in untrained fish. Their observation appears to contradict that observed by Rush \& Umminger (1978) and by us. In Woodward \& Smith's (1985) experiment, however, 
trout were preconditioned by exercise training and not by similar disturbances, suggesting the possible importance of the novelty factor in elicitation of a stress response in fish.

The maximum post-stress cortisol response was much lower in the $5 \mathrm{~g}$ fish at Week 0 (Fig. 3) than it was in $21 \mathrm{~g}$ control fish handled for the first time at Week 10 (Fig. 7). An increase over time in the stress response was previously demonstrated in smolting coho salmon (Barton et al. 1985a) and may reflect an increased interrenal responsiveness to stress associated with juvenile development in fish. Similarly, 1 h post-stress plasma glucose was lower in fish from Week 0 (Fig. 5) than in control fish stressed at Week 10 (Fig. 8), suggesting that the change in sensitivity or responsiveness of fish to stress may be a general developmental phenomenon.

Acknowledgements. We thank C. S. Bradford, Oregon Cooperative Fishery Research Unit, for helping with sample collections; Dr W. T Yasutake, U.S. Fish and Wildlife Service, for examining slide mounts of stomach tissue; and the Western Fish Toxicology Station, Environmental Protection Agency, for providing the fish. We are also grateful to A. G. Maule, Oregon Cooperative Fishery Research Unit, and Drs. L. J. Weber, L. R. Curtis, and F. L. Moore, Oregon State University, for reviewing the manuscript. Mention of trade names or manufacturers does not imply U.S. Government endorsement of commercial products.

\section{LITERATURE CITED}

Ball, J. N., Hawkins, E. F. (1976). Adrenocortical (interrenal) responses to hypophysectomy and adenohypophysial hormones in the teleost Poecilia latipinna. Gen. Comp. Endocrinol. 28: 59-70

Barton, B. A., Peter, R. E., Paulencu, C. R. (1980). Plasma cortisol levels of fingerling rainbow trout (Salmo gairdneri) at rest, and subjected to handling, confinement, transport, and stocking. Can. J. Fish. Aquat. Sci. 37. 805-811

Barton, B. A., Schreck, C. B. (in press a). Metabolic cost of acute physical stress in juvenile steelhead trout. Trans. Am. Fish. Soc. 116

Barton, B. A., Schreck, C. B. (in press b). Influence of acclimation temperature on interrenal and carbohydrate stress responses in juvenile chinook salmon (Oncorhynchus tshawytscha). Aquaculture 62

Barton, B. A., Schreck, C. B., Ewing, R. D., Hemmingsen, A. R., Patiño, R. (1985a). Changes in plasma cortisol during stress and smoltification in coho salmon, Oncorhynchus kisutch. Gen. Comp. Endocrinol. 59: 468-471

Barton, B. A., Schreck, C. B., Sigismondi, L. A. (1986). Multiple acute disturbances evoke cumulative physiological stress responses in juvenile chinook salmon. Trans. Am. Fish. Soc. 115: 245-251

Barton, B. A., Weiner, G. S., Schreck, C. B. (1985b). Effect of prior acid exposure on physiological responses of juvenile rainbow trout (Salmo gairdneri) to acute handling stress. Can. J. Fish. Aquat. Sci. 42: 710-717

Basu, J., Nandi, J., Bern, H. A. (1965). The homolog of the pituitary-adrenocortical axis in the teleost fish Tilapia mossambica. J. exp. Zool. 159: 347-356
Brett, J. R., Groves, T D. D. (1979). Physiological energetics. In: Hoar, W. S., Randall, D. J., Brett, J. R. (ed.) Fish physiology, Vol. VIII, Bioenergetics and growth. Academic Press, New York, p. 279-352

Butler, D. G. (1968). Hormonal control of gluconeogenesis in the North American eel (Anguilla rostrata). Gen. Comp. Endocrinol. 10: 85-91

Carmichael, G. J., Tomasso, J. R., Simco, B. A., Davis, K. B. (1984). Confinement and water quality-induced stress in largemouth bass. Trans. Am. Fish. Soc. 113: 767-777

Chan, D. K. O., Rankin, J. C., Chester Jones, I. (1969). Influences of the adrenal cortex and the corpuscles of Stannius on osmoregulation in the European eel (Anguilla anguilla L.) adapted to freshwater. Gen. Comp. Endocrinol. (Suppl. 2): 342-353

Chan, D. K. O., Woo, N. Y. S. (1978). Effect of cortisol on the metabolism of the eel, Anguilla japonica. Gen. Comp. Endocrinol. 35: 205-215

Davis, K. B., Torrance, P., Parker, N. C., Suttle, M. A. (1985). Growth, body composition and hepatic tyrosine aminotransferase activity in cortisol-fed channel catfish, Ictalurus punctatus Rafinesque. J. Fish Biol. 27: 177-184

Donaldson, E. M. (1981). The pituitary-interrenal axis as an indicator of stress in fish. In: Pickering, A. D. (ed.) Stress and fish. Academic Press, London, p. 11-47

Ellsaesser, C. F. Clem, L. W. (1986). Haematological and immunological changes in channel catfish stressed by handling and transport. J. Fish Biol. 28: 511-521

Esch, G. W., Hazen, T C. (1980). Stress and body condition in a population of largemouth bass: implications for red-sore disease. Trans. Am. Fish. Soc. 109: 532-536

Foster, L. B., Dunn, R. T. (1974). Single-antibody technique for radioimmunoassay of cortisol in unextracted serum or plasma. Clin. Chem. 20:365-368

Frenkl, R., Csalay, L., Csalkvary, G., Zelles, T (1968). Effect of muscular exertion on the reaction of the pituitaryadrenocortical axis in trained and untrained rats. Acta Physiol. Acad. Sci. Hung. 33: 435-438

Fries, C. R. (1986). Effects of environmental stressors and immunosuppressants on immunity in Fundulus heteroclitus. Am. Zool. 26: 271-282

Fryer, J. N., Peter, R. E. (1977). Hypothalamic control of ACTH secretion in goldfish. III. Hypothalamic cortisol implant studies. Gen. Comp. Endocrinol. 33: 215-225

Grimm, A. S. (1985). Suppression by cortisol of the mitogeninduced proliferation of peripheral blood leucocytes from plaice, Pleuronectes platessa L. In: Manning, M. J., Tatner, M. F. (ed.) Fish immunology. Academic Press, London, p. $263-271$

Hill, C. W., Fromm, P. O. (1968). Response of the interrenal gland of rainbow trout (Salmo gairdneri) to stress. Gen. Comp. Endocrinol. 11: 69-77

Hlavek, R. R., Bulkley, R. V. (1980). Effects of malachite green on leucocyte abundance in rainbow trout, Salmo gairdneri (Richardson). J. Fish Biol. 17: 431-444

Inui, Y., Yokote, M. (1975). Gluconeogenesis in the eel - IV Gluconeogenesis in the hydrocortisone-administered eel. Bull. Jap. Soc. scient. Fish. 41. 973-981

Johansson-Sjobeck, M.-L., Dave, G., Larrson, A., Lewander, K., Lidman, U. (1978). Hematological effects of cortisol in the European eel, Anguilla anguilla L. Comp. Biochem. Physiol. 60A: 165-168

Klinger, H., Delventhal, H., Hilge, V. (1983). Water quality and stocking density as stressors of channel catfish (Ictalurus punctatus Raf.). Aquaculture 30: 263-272 
Leach, G. J., Taylor, M. H. (1980). The role of cortisol in stressinduced metabolic changes in Fundulus heteroclitus. Gen. Comp. Endocrinol. 42: 219-227

Leach, G. J., Taylor, M. H. (1982). The effects of cortisol treatment and protein metabolism in Fundulus heteroclitus. Gen. Comp. Endocrinol. 48: 76-83

Leatherland, J. F. (1985). Studies of the correlation between stress-response, osmoregulation and thyroid physiology in rainbow trout, Salmo gairdnerii (Richardson). Comp. Biochem. Physiol. 80A: 523-531

Levine, S. (1985). A definition of stress? In: Moberg, G. P. (ed.) Animal stress. American Physiological Society, Bethesda, p. 51-69

Lidman, U., Dave, G., Johansson-Sjobeck, M.-L., Larsson, A., Lewander, K. (1979). Metabolic effects of cortisol in the European eel, Anguilla anguilla (L.). Comp. Biochem. Physiol. 63A: 339-344

Maule, A. G., Schreck, C. B., Kaattari, S. L. (1987). Changes in the immune system of coho salmon (Oncorhynchus kisutch) during the parr-to-smolt transformation and after implantation of cortisol. Can. J. Fish. Aquat. Sci. 44: $161-166$

Mazeaud, M. M., Mazeaud, F. (1981). Adrenergic responses to stress in fish. In: Pickering, A. D. (ed.) Stress and fish. Academic Press, London, p. 49-75

Mazeaud, M. M., Mazeaud, F., Donaldson, E. M. (1977). Primary and secondary effects of stress in fish: some new data with a general review. Trans. Am. Fish. Soc. 106: 201-212

McBride, J. R., van Overbeeke, A. P. (1971). Effects of androgens, estrogens, and cortisol on the skin, stomach, liver, pancreas, and kidney in gonadectomized adult sockeye salmon (Oncorhynchus nerka). J. Fish. Res. Bd Can. 28: 485-490

McLeay, D. J. (1973). Effects of cortisol and dexamethasone on the pituitary-interrenal axis and abundance of white blood cell types in juvenile coho salmon, Oncorhynchus kisutch. Gen. Comp. Endocrinol. 21: 441-450

Mcleay, D. J., Gordon, M. R. (1977). Leucocrit: a simple hematological technique for measuring acute stress in salmonid fish, including stressful concentrations of pulpmill effluent. J. Fish. Res. Bd Can. 34: 2164-2175

Milligan, C. L., Wood, C. M. (1982). Disturbances in haematology, fluid volume distribution and circulatory function associated with low environmental $\mathrm{pH}$ in the rainbow trout, Salmo gairdneri. J. exp. Biol. 99: 397-415

Montgomery, R. (1957). Determination of glycogen. Arch. Biochem. Biophys. 67: 378-386

Nakano, T., Tomlinson, N. (1967). Catecholamine and carbohydrate concentrations in rainbow trout (Salmo gairdneri) in relation to physical disturbance. J. Fish. Res. Bd Can. 24: 1701-1715

Nichols, D. J., Weisbart, M. (1985). Cortisol dynamics during seawater adaptation of Atlantic salmon Salmo salar. Am. J. Physiol. 248: R651-R659

Nichols, D. J., Weisbart, M., Quinn, J. (1985). Cortisol kinetics and fluid distribution in brook trout (Salvelinus fontinalis). J. Endocrinol. 107: 57-69

Patent, G. J. (1970). Comparison of some hormonal effects on carbohydrate metabolism in an elasmobranch (Squalus acanthias) and a holocephalan (Hydrolagus colliei). Gen. Comp. Endocrinol, 14: 215-242

Paxton, R., Gist, D. H., Umminger, B. L. (1984). Serum cortisol levels in thermally-acclimated goldfish (Carassius auratus) and killifish (Fundulus heteroclitus): implications in control of hepatic glycogen metabolism. Comp. Biochem. Physiol. 78B: 813-816
Peters, G. (1982). The effect of stress on the stomach of the European eel, Anguilla anguilla L. J. Fish Biol. 21: 497-512

Peters, G., Delventhal, H., Klinger, H. (1980). Physiological and morphological effects of social stress in the eel (Anguilla anguilla L.). Arch. FischWiss. 30: 157-180

Peters, G., Schwarzer, R. (1985). Changes in hemopoietic tissue of rainbow trout under influence of stress. Dis. Aqual. Org. 1: 1-10

Pickering, A. D. (ed.) (1981). Stress and fish. Academic Press, London

Pickering, A. D. (1984). Cortisol-induced lymphocytopenia in brown trout, Salmo trutta L. Gen. Comp. Endocrinol. 53: $252-259$

Pickering, A. D., Duston, J. (1983). Administration of cortisol to brown trout, Salmo trutta L., and its effects on the susceptibility to Saprolegnia infection and furunculosis. J. Fish Biol. 23: 163-175

Pickering, A. D., Pottinger, T. G. (1983). Seasonal and diel changes in plasma cortisol levels of the brown trout, Salmo trutta L. Gen. Comp. Endocrinol. 49: 232-239

Pickering, A. D., Pottinger, T. G. (1985). Acclimation of the brown trout, Salmo trutta L., to the stress of daily exposure to malachite green. Aquaculture 44: 145-152

Pickering, A. D., Pottinger, T. G., Christie, P. (1982). Recovery of the brown trout, Salmo trutta L., from acute handling stress: a time-course study. J. Fish Biol. 20: 229-244

Pickering, A. D., Pottinger, T. G., Sumpter, J. P. (1986). Independence of the pituitary-interrenal axis and melanotroph activity in the brown trout, Salmo trutta L., under conditions of environmental stress. Gen. Comp. Endocrinol. 64: 206-211

Pickering, A. D., Stewart, A. (1984). Acclimation of the interrenal tissue of the brown trout, Salmo trutta L., to chronic crowding stress. J. Fish Biol. 24: 731-740

Pickford, G. E., Pang, P. K. T., Weinstein, E., Torretti, J., Hendler, E., Epstein, F. H. (1970). The response of the hypophysectomized cyprinodont, Fundulus heteroclitus, to replacement therapy with cortisol: effects on blood serum and sodium-potassium activated adenosine triphosphatase in the gills, kidney, and intestinal mucosa. Gen. Comp. Endocrinol. 14: 524-534

Redding, J. M., Patiño, R., Schreck, C. B. (1984a). Clearance of corticosteroids in yearling coho salmon, Oncorhynchus kisutch, in fresh water and seawater and after stress. Gen. Comp. Endocrinol. 54: 433-443

Redding, J. M., Schreck, C. B. (1983). Influence of ambient salinity on osmoregulation and cortisol concentration in yearling coho salmon during stress. Trans. Am. Fish. Soc. 112: 800-807

Redding, J. M., Schreck, C. B., Birks, E. K, Ewing, R. D. (1984b). Cortisol and its effects on plasma thyroid hormone and electrolyte concentrations in fresh water and during seawater acclimation in yearling coho salmon, Oncorhynchus kisutch. Gen. Comp. Endocrinol. 56: 146-155

Rees, A., Harvey, S., Phillips, J. G. (1983). Habituation of the corticosterone response of ducks (Anas platyrhynchos) to daily treadmill exercise. Gen. Comp. Endocrinol. 49: 485-489

Rees, A., Harvey, S., Phillips, J. G. (1985). Transitory corticosterone responses of ducks (Anas platyrhynchos) to exercise. Gen. Comp. Endocrinol. 59: 100-104

Ricker, W. E. (1979). Growth rates and models. In: Hoar, W. S., Randall, D. J., Brett, J. R. (ed.) Fish physiology, Vol. VIII, Bioenergetics and growth. Academic Press, New York, p. $677-743$

Robertson, O. H., Hane, S., Wexler, B. C., Rinfret, A. P. (1963). 
The effect of hydrocortisone on immature rainbow trout (Salmo gairdnerii). Gen. Comp. Endocrinol. 3: 422-436

Roth, R. R. (1972). Some factors contributing to the development of fungus infection in freshwater fish. $J$. Wildl. Dis. 8: $24-28$

Rush, S. B., Umminger, B. L. (1978). Elimination of stressinduced changes in carbohydrate metabolism of goldfish (Carassius auratus) by training. Comp. Biochem. Physiol. 60A: 69-73

Schmidt, P. J., Idler, D. R. (1962). Steroid hormones in the plasma of salmon at various states of maturation. Gen. Comp. Endocrinol. 2: 204-214

Schreck, C. B. (1981). Stress and compensation in teleostean fishes: response to social and physical factors. In: Pickering, A. D. (ed.) Stress and fish. Academic Press, London, p. $295-321$

Snedecor, G. W., Cochran, W. G. (1967). Statistical methods, 6 th edn. Iowa State University Press, Ames

Snieszko, S. F. (1974). The effects of environmental stress on outbreaks of infectious diseases of tishes. J. Fish Biol. 6: $197-208$

Soivio, A., Oikari, A. (1976). Haematological effects of stress on a teleost, Esox lucius L. J. Fish Biol. 8: 397-411

Steel, R. G. D., Torrie, J. H. (1980). Principles and procedures of statistics, 2nd edn. McGraw-Hill, New York

Storer, J. H. (1967). Starvation and the effects of cortisol in the goldfish (Carassius auratus L.). Comp. Biochem. Physiol. 29: 939-948

Strange, R. J., Schreck, C. B. (1980). Seawater and confinement alters survival and cortisol concentration in juvenile chinook salmon. Copeia 1980: 351-353

Strange, R. J., Schreck, C. B., Ewing, R. D. (1978). Cortisol concentrations in confined juvenile chinook salmon (Oncorhynchus tshawytscha). Trans. Am. Fish. Soc. 107: $812-819$

Strange, R. J., Schreck, C. B., Golden, J. T. (1977). Corticoid stress responses to handling and temperature in salmonids. Trans. Am. Fish. Soc. 106: 213-217

Swallow, R. L., Fleming, W. R. (1970). The effect of oxaloacetate, ACTH and cortisol on the liver glycogen levels of Tilapia mossambica. Comp. Biochem. Physiol. 36: 93-98
Tharp, G. D., Buuck, R. J. (1974). Adrenal adaptation to chronic exercise. J. appl. Physiol. 37: 720-722

Tomasso, J. R., Simco, B. A., Davis, K. B. (1983). Circulating corticosteroid and leucocyte dynamics in channel catfish during net confinement. Tex. J. Sci. 35: 83-88

Umminger, B. L. (1977). Relation of whole blood sugar concentrations in vertebrates to standard metabolic rate. Comp. Biochem. Physiol 56A: 457-460

Wagner, G. F., Mckeown, B. A. (1985). Cyclical growth in juvenile rainbow trout, Salmo gairdneri. Can. J. Zool. 63: 2473-2474

Walters, G. R., Plumb, J. A. (1980). Environmental stress and bacterial infection in channel catfish, Ictalurus punctatus Rafinesque. J. Fish Biol. 17: 177-185

Wedemeyer, G. (1970). The role of stress in the disease resistance of fishes. In: Snieszko, S. F. (ed.) A symposium on diseases of fishes and shellfishes. Am. Fish. Soc. Spec. Publ. 5: 30-35

Wedemeyer, G. A., Goodyear, C. P. (1984). Diseases caused by environmental stressors. In: Kinne, O. (ed.) Diseases of marine animals, Vol. IV, Part 1, Pisces. Biologische Anstalt Helgoland, Hamburg, p. 424-434

Wedemeyer, G. A., Gould, R. W., Yasutake, W. T. (1983). Some potentials and limits of the leucocrit test as a fish health assessment method. J. Fish Biol. 23: 711-716

Wedemeyer, G. A., Yasutake, W T (1977). Clinical methods for the assessment of the effects of environmental stress on fish health. U.S. Fish Wildl, Serv. Tech. Pap. 89

Wells, R. M. G., Tetens, V., Devries, A. L. (1984). Recovery from stress following capture and anaesthesia of antarctic fish: haematology and blood chemistry. J. Fish Biol. 25: $567-576$

Willemse, J. J., Markus-Silvis, L., Ketting, G. H. (1984). Morphological effects of stress in cultured elvers, Anguilla anguilla (L.). Aquaculture 36: 193-201

Woodward, J. J., Smith, L. S. (1985). Exercise training and the stress response in rainbow trout, Salmo gairdneri Richardson. J. Fish Biol. 26: 435-447

Yasutake, W T., Wales, J. H. (1983). Microscopic anatomy of salmonids: an atlas. U.S. Fish Wildl, Serv. Resour. Publ. 150 